\title{
Sistem Pakar Mendiagnosa Penyakit Dan Hama Penyerang Tanaman Bougenville Dengan Metode Teorema Bayes
}

\author{
Muhammad Romi Fadillah, Beni Andika, Darjat Saripurna, \\ Program Studi Sistem Informasi, STMIK Triguna Dharma
}

\begin{tabular}{|c|c|}
\hline Article Info & ABSTRACT \\
\hline Article history: & $\begin{array}{l}\text { Bougenville atau disebut sebagai "Bunga Kertas" merupakan salah satu jenis } \\
\text { tanaman yang banyak kita jumpai di wilayah tropis seperti Indonesia. Bunga }\end{array}$ \\
\hline Received Jun $12^{\text {th }}, 2020$ & $\begin{array}{l}\text { kertas sendiri terbilang cukup popoler di indonesia, sering digunakan sebagai } \\
\text { aksen penghias tanaman. Bunga ini dinamakan bunga kertas karena memang }\end{array}$ \\
\hline Revised Aug 20 ${ }^{\text {th }}, 2020$ & $\begin{array}{l}\text { memiliki kelopak dengan tekstur yang mirip kertas. Dibeberapa daerah } \\
\text { banyak orang yang menyebut bunga kertas dengan nama "Bunga Zinnia". }\end{array}$ \\
\hline \multirow[t]{2}{*}{ Accepted Aug 26 ${ }^{\text {th }}, 2020$} & $\begin{array}{l}\text { Bunga jenis ini merupakan salah satu bunga yang dapat dikatakan mudah } \\
\text { untuk dibudidayakan. }\end{array}$ \\
\hline & $\begin{array}{l}\text { Dengan adanya rancangan sisem pakar berbasis web ini mempermudah } \\
\text { masyarakat umum dalam mendapatkan informasi terkait penyakit dan hama }\end{array}$ \\
\hline Keyword: & penyerang tanaman aglaonema. Hasil mendiagnosa dengan sistem ini \\
\hline Penelitian, Pengamatan & $\begin{array}{l}\text { menunjukkan bahwa sistem mampu mempermudah mengetahui penyakit dan } \\
\text { hama penyerang tanaman aglaonema berdasarkan indikator-indikator yang }\end{array}$ \\
\hline Mendiagnosa & dipilih oleh pengguna sistem pakar. \\
\hline
\end{tabular}

Sistem Pakar

Teorema Bayes

Corresponding Author: *First Author

Nama : Muhammad Romi Fadillah

Kantor : STMIK Triguna Dharma

Program Studi : Sistem Informasi

E-Mail : mhdromi@gmail.com

\section{PENDAHULUAN}


Bougenville adalah tanaman hias yang sangat populer dan banyak ditanam dipekarangan rumah, taman kota maupun sebagai penghias di pinggir jalan. Pohon bougenville termasuk berbatang kecil yang sulit tumbuh dengan tegak namun untuk spesies tertentu batangnya bisa sebesar pohon kelapa.

Selain dinikmati karena keelokan warna-warni bunganya, Bougenville sebernarnya patut ditanam dipekatangan karena mengandung berbagai manfaat herbal. Daun, Bunga, Akar dan kulit batang Bougenville mengandung sapoin dan polifenol. Bougenville tidak hanya dapat menjadi tanaman hias, tetapi juga dapat berguna sebagai obat untuk mencegah berbagai jenis penyakit seperti hepatitis, penyakit bisul, obat keputihan, haid tidak teratur, dan lain sebagainya.

perkembangan informasi yang semakin meningkat, teknologi sangat berperan penting dalam perkembangan informasi bagi semua pihak. salah satunya bagian terpenting dalam peningkatan teknologi informasi. Suatu sistem dalam ilmu yang berkaitan dengan penyimpanan informasi aturan-aturan penalaran yang memungkinkan komputer dapat mengambil keputusan layaknya seorang pakar dalam suatu bidang tertentu disebut dengan sistem pakar

Metode Teorema Bayes adalah strategi untuk memprediksi atau mencari solusi dari suatu masalah yang dimulai dengan sekumpulan fakta yang diketahuin akan menurunkan fakta baru.

\section{METODE PENELITIAN}

\subsection{Sistem Pakar}

Sistem pakar adalah suatu sistem yang dirancang untuk dapat menirukan keahlian seseorang pakar dalam menjawab pertanyaan dan memecahkan suatu masalah. Sistem pakar akan memberikan pemecahan suatu masalah yang didapat dari dialog dengan pengguna. Dengan bantuan sistem pakar seseorang yang bukan pakar/ahli dapat menjawab pertanyaan, menyelesaikan masalah serta mengambil keputusan yang biasanya dilakukan oleh seseorang pakar (T.Sutojo dkk, 2017:13).

Ada beberapa defenisi sistem pakar, antara lain:

1. Menurut Turban (dalam T. Sutojo dkk, 2017:160)

'Sistem pakar adalah sebuah sistem yang menggunakan pengetahuan manusia dimana pengetahuan tersebut dimasukkan kedalam sebuah komentar dan kemudian digunakan untuk menyelesaikan masalah-masalah yang biasanya membutuhkan kepakaran atau keahlian manusia'.

2. Menurut Jackson (dalam T. Sutojo dkk , 2017:160) 'Sistem pakar adalah program komputer yang mempresentasikan dan melakukan penalaran dengan pengetahuan beberapa pakar untuk memecahkan masalah atau memberi saran'.

3. Menurut Luger dan Stubblefield (dalam T. Sutojo dkk , 2017:160)

'Sistem pakar adalah program yang berbasiskan pengetahuan yang menyediakan solusi 'kualitas pakar' kepada masalah-masalah dalam bidang (domain) yang spesifik'.

\subsubsection{Manfaat Sistem Pakar}

Sistem pakar menjadi sangat popular karena banyak kemampuan dan manfaat yang diberikannya,diantanya

1. Meningkatkan produktifitas, karena sistem pakar dapat bekerja lebih cepat dari pada manusia. Subsistem

2. Membuat seseorang yang awam bekerja seperti layaknya seorang pakar.

3. Meningkatkan kualitas dengan memberi nasehat yang konsisten dan mengurangi kesalahan.

4. Mampu menangkap pengetahuan dan kepakaran seseorang.

5. Dapat beroperasi di lingkungan yang barbahaya.

6. Memudahkan akses pengetahuan seorang pakar.

7. Andal, sistem pakar tidak pernah menjadi bosan dan kelelahan atau sakit.

8. Meningkatkan kapasitas sistem komputer. Integrasi sistem pakar dengan sistem komputer lain membuat sistem lebih efektif dan mencakup lebih banyak aplikasi.

9. Mampu bekerja dengan informasi yang tidak lengkap atau tidak pasti. Berbeda dengan sistem komputer konvensional, sistem pakar dapat bekerja dengan informasi yang tidak lengkap. Pengguna dapat 
merespons dengan "tidak tahu" atau "tidak yakin" pada satu atau lebih pertanyaan selama konsultasi dan sistem pakar tetap akan memberikan jawabannya.

10. Bisa digunakan sebagai media pelengkap dalam pelatihan. Pengguna pemula yang bekerja dengan sistem pakar akan menjadi lebih berpengalaman karena adanya fasilitas penjelas yang berfungsi sebagai guru.

11. Meningkatkan kemampuan menyelesaikan masalah karena sistem pakar mengambil sumber pengetahuan dari banyak pakar. (T.Sutojo dkk, 2017:160).

\subsubsection{Kekurangan Sistem Pakar}

Beberapa kekurangan yang ada pada sistem pakar, diantaranya:

1. Biaya yang sangat mahal untuk membuat dan memeliharanya.

2. Sulit dikembangkan karena keterbatasan keahlian dan ketersediaan pakar.

3. Sistem pakar tidak $100 \%$ bernilai benar. (T. Sutojo dkk, 2017:161).

\subsubsection{Ciri-Ciri Sistem Pakar}

Ciri-ciri dari sistem pakar adalah sebagai berikut:

1. Terbatas pada domain keahlian tertentu.

2. Dapat memberikan penalaran untuk data-data yang tidak lengkap atau tidak pasti.

3. Dapat menjelaskan alasan-alasan dengan cara yang dapat dipahami.

4. Bekerja berdasarkan kaidah/rule tertentu.

5. Mudah dimodifikasi.

6. Basis pengetahuan dan mekanisme interferensi terpisah.

7. Keluarannya bersifat anjuran.

8. Sistem dapat mengaktifkan kaidah secara searah yang sesuai, dituntut oleh dialog dengan pengguna. (T.Sutojo dkk, 2017:162).

\subsubsection{Area Permasalahan Sistem Pakar}

Aplikasi sistem pakar menyentuh beberapa area permasalahan yaitu sebagai berikut: (T. Sutojo dkk, 2017:162)

1. Interpretasi: menghasilkan deskripsi situasi berdasarkan data-data masukan.

2. Prediksi: memperkirakan akibat yang mungkin terjadi dari situasi yang ada.

3. Diagnosis: menyimpulkan suatu keadaan berdasarkan gejala-gejala yang diberikan (symptopms).

4. Desain: melakukan perancangan berdasarkan kendala-kendala yang diberikan.

5. Planning: merencanakan tindakan-tindakan yang akan dilakukan.

6. Monitoring: membandingkan hasil pengamatan dengan proses perencanaan.

7. Debugging: menentukan penyelesaian dari suatu kesalahan sistem.

8. Reparasi: melaksanakan rencana perbaikan.

9. Instruction: melakukan instruksi untuk diagnosis, debugging, dan perbaikan kinerja.

10.control: melakukan kontrol terhadap hasil interpretasi, diagnosis, debugging, monitoring, dan perbaikan tingkah laku sistem

\subsection{Tanaman Bougenville}

Bougenville atau disebut juga sebagai “ Bunga Kertas” merupakan salah satu jenis tanaman yang banyak kita jumpai di wilayah tropis seperti indonesia. Bunga kertas sendiri terbilang cukup populer di indonesia, sering digunakan sebagai aksen penghias tanaman. Bunga ini dinamakan bunga kertas karena memang memiliki kelompak dengan tekstur yang mirip kertas.di beberapa daerah banyak orang yang menyebut bunga kertas dengan nama “ Bunga Zinnia”. Bunga jenis ini merupakan salah satu bunga yang dapat dikatakan mudah untuk di budidayakan.

Sumber: Teguh El Real.Tanaman Hias Bunga, Daun \& Bonsai.2016:38.

\subsubsection{Penyakit Tanaman Bougenville}

Adapun jenis penyakit yang menyerang tanaman Bougenville adalah :

1. Penyakit Layu Bakteri

Penyakit pada tanaman Bougenville disebabkan oleh 2 patogen, yaitu cendawan dab bakteri. Jumlah cendawan yang menyebabkan penyakit pada umumnya lebih banyak dibanding bakteri. Layu bakteri ditandai dengan daun dan batang yang menguning.

2. Ulat Kantong

Hama ini menyerang bagian daun. tanaman menjadi berlubang, menggulung, dan daunnya keriting.

Jurnal SAINTIKOM Vol. 19, No. 1, Februari 2020:82-87 
3. Kutu Putih

Hama ini menyerang bagian daun. tanaman menjadi berlubang, menggulung, dan daunnya keriting.

4. Layu Fusarium

Gejala serangan ditandai dengan tulang daun yang pucat berubah warna menjadi coklat keabuan kemudian tangkainya membusuk. Penyebabnya adalah media yang selalu basah sehingga media tanam ber-PH rendah. Kondisi tersebut membuat Fusarium Oxysporium cepat berkembang.

\subsubsection{Jenis-Jenis Tanaman Bougenville}

Ada beberapa jenis tanaman Bougenville, yaitu :

1. Bougenville California Gold

Bunga ini menghasilakan bunga yang berubah dari emas pucat sampai jingga perunggu, karena ketika bunga ini mekar tidak lama kemudian menggugurkannya.

2. Bougenville Gold Rush

Bunga ini memiliki warna kuning keemasan yang mencolok dan lebih terang dari varietas lain.

3. Bougenville After Glow

Bunga ini mekar berulang kali sepanjang tahun. Bunganya bewarna orange, merah muda dan coral. Dedaunnya yang halus namun berstektur berwarna hijau sepanjang tahun.

4. Bougenville Bambino Baby Allison

Bunga ini berwarna merah muda, mekar di akhir musim semi, awal musim panas, pertengahan musim panas dan diawal musim gugur. Dedaun bewarna hijau sepanjang tahun.

5 Bougenville Cherry Blossom

Bunga ini adalah bunga yang mekar berwarna merah muda dan ada pula yang

hampir putih. Mekar berulang kali di akhir musim semi, awal musim panas,

pertengahan musim panas dan diawal musim gugur

\subsection{Teorema Bayes}

Teorema Bayes merupakan suatu metode yang digunakan untuk menghitung ketidakpastian data menjadi data yang pasti dengan membandingkan antara data yang ya dan tidak. Probabilitas bayes merupakan salah satu cara untuk mengatasi ketidakpastian data dengan cara menggunakan formula bayes yang dinyatakan dengan:

$$
P(P \mid E)=\frac{P(E \mid H) \cdot P(H)}{P(E)}
$$

Dengan:

$\mathrm{P}(\mathrm{H} \mid \mathrm{E}) \quad=$ Probabilitas hipotesis $\mathrm{H}$ jika diberikan evidence $\mathrm{E}$.

$\mathrm{P}(\mathrm{E} \mid \mathrm{H}) \quad=$ Probabilitas munculnya evidence $\mathrm{E}$, jika diketahui Hipotesis $\mathrm{H}$.

$\mathrm{P}(\mathrm{H}) \quad=$ Probabilitas hipotesis $\mathrm{H}$ tanpa memandang evidence apapun.

$\mathrm{P}(\mathrm{E}) \quad=$ Probabilitas evidence $\mathrm{E}$.

\section{ANALISA DAN PERANCANGAN}

Aplikasi sistem pakar yang dirancang menggunakan metode Teorema Bayes melakukan perhitungan berdasarkan data konsultan penguna yang ada menjadi data pengetahuan bagi sistem yang dirancang. Aplikasi diharapkan dapat menkonsultasi penyakit pada tanaman aglaonema yang akan menghasilkan Out Put berupa kemungkinan dari jenis penyakit pada tanaman aglaonema dengan kesimpulan dan solusi.

\subsection{Algoritma Sistem}

Algoritma sistem merupakan sebuah tahapan yang dilakukan sebelum proses menentukan diagnosa penyakit dan hama tanaman Bougenville . Adapun algoritma sistemnya yaitu :

\subsubsection{Membentuk Basis Pengetahuan}

Pengetahuan sistem pakar merupakan pemindahan pengetahuan kepakaran dari seorang pakar ke dalam sebuah sistem komputer dengan pemanfaatan yang ada. Pengembangan dari seorang pakar yang akan 
dituangkan dalam sebuah tabel sebagai media penyimpanan pengetahuan yang nantinya akan menjadi sumber pengetahuan oleh komputer tersebut.

Berikut tabel basis pengetahuan yang akan digunakan dalam mendiagnosa penyakit tanaman Bougenville sebagai berikut :

Tabel 3.1 Gejala Tanaman Bougenville

\begin{tabular}{|c|c|c|}
\hline No & Gejala & Kode Gejala \\
\hline 1 & Pembusukan pada bagian pucuk tanaman & G1 \\
\hline 2 & Tulang daun berubah warna kekuningan & $\mathrm{G} 2$ \\
\hline 3 & Terdapat pucuk tanaman mengecil & G3 \\
\hline 4 & Adanya pembusukan di daun & G4 \\
\hline 5 & Daun membusuk diujung & G5 \\
\hline 6 & Terdapat bercak hitam didaun & G6 \\
\hline 7 & Terdapat lubang didaun & G7 \\
\hline 8 & Daun menggulung dan keriting & G8 \\
\hline 9 & Terdapat bintik-bintik putih dibelakang daun & G9 \\
\hline 10 & Terdapat bintik-bintik putih dibatang & G10 \\
\hline 11 & Terdapat bitik-bintik putih diakar tanaman & G11 \\
\hline 12 & Tulang daun berubah warna kecoklatan & G12 \\
\hline 13 & Batang dan akar tanaman mengering & G13 \\
\hline 14 & Adanya pembusukan ditangkai daun & G14 \\
\hline
\end{tabular}

Sumber : Upt Pengembangan Bibit Hortikultura Dan Peternakan Kota Medan

Tabel 3.2 Jenis penyakit dan solusi penanggulangan tanaman Bougenville

\begin{tabular}{|c|c|l|l|}
\hline No & $\begin{array}{c}\text { Kode } \\
\text { Penyakit }\end{array}$ & Nama Penyakit & Solusi Penanggulangan \\
\hline 1 & P001 & Layu Bakteri & $\begin{array}{l}\text { Dengan menyemprotkan bakterisida setiap dua } \\
\text { kali seminggu }\end{array}$ \\
\hline 2 & P002 & Ulat Kantong & $\begin{array}{l}\text { Menyemprotkan fungsida atau dengan } \\
\text { menggunakan score dosis 1cc/L }\end{array}$ \\
\hline 3 & P003 & Kutu Putih & $\begin{array}{l}\text { Menyemprot Insektisida dengan dosis } 1 \mathrm{ml} / \mathrm{L} \\
\text { air diberikan tiga hari sekali }\end{array}$ \\
\hline 4 & P004 & Layu Fusarium & $\begin{array}{l}\text { Mengganti media tanaman atau dapat juga } \\
\text { menyiram fungsida per 2 minggu }\end{array}$ \\
\hline
\end{tabular}

Sumber : Upt Pengembangan Bibit Hortikultura Dan Peternakan Kota Medan

Tabel 3.3 Keputusan antara penyakit dan gejala 


\begin{tabular}{|c|c|c|c|c|}
\hline $\begin{array}{c}\text { Kode } \\
\text { Gejala }\end{array}$ & P001 & P002 & P003 & P004 \\
\hline G1 & 1 & 0 & 0 & 0 \\
\hline G2 & 1 & 0 & 0 & 0 \\
\hline G3 & 1 & 0 & 0 & 0 \\
\hline G4 & 1 & 0 & 0 & 0 \\
\hline G5 & 0 & 1 & 0 & 0 \\
\hline G6 & 0 & 1 & 0 & 0 \\
\hline G7 & 0 & 1 & 0 & 0 \\
\hline G8 & 0 & 1 & 0 & 0 \\
\hline G9 & 0 & 0 & 1 & 0 \\
\hline G10 & 0 & 0 & 1 & 0 \\
\hline G11 & 0 & 0 & 1 & 0 \\
\hline G12 & 0 & 0 & 0 & 1 \\
\hline G13 & 0 & 0 & 0 & 1 \\
\hline G14 & 0 & 0 & 0 & 1 \\
\hline
\end{tabular}

\subsubsection{Membentuk Rule (Basis Aturan)}

Dalam menentukan jenis penyakit yaitu penyakit tanaman Bougenville maka dibuatlah rulenya terlebih dahulu berdasarkan kaidah sistem pakar dengan metode Teorema Bayes adalah sebagai berikut :

1. Rule 1 :

IF Pembusukan pada bagian pucuk tanaman = Yes And Tulang daun berubah warna kekuningan = Yes And Terdapat pucuk tanaman mengecil $=$ Yes And Adanya pembusukan didaun $=$ Yes Then Penyakit $=$ Layu Bakteri

2. Rule 2:

IF Daun Membusuk di ujung = Yes And Terdapat bercak hitam di daun = Yes And Terdapat lubang didaun = Yes And Daun Menggulung dan Keriting $=$ Yes Then Penyakit $=$ Ulat Kantong

3. Rule 3:

IF Terdapat bintik putih dibelakang daun = Yes And Terdapat Bintik putih dibatang = Yes And Terdapat bintik putih diakar tanaman $=$ Yes Then Penyakit $=$ Kutu Putih

4. Rule 4:

IF Tulang daun berubah warna kecoklatan = Yes And Batang dan akar tanaman mengering $=$ Yes And Adanya pembusukan ditangkai daun $=$ Yes Then Penyakit $=$ Layu Fusarium

Dibawah ini merupakan tabel kode penyakit, gejala, kode gejala, nilai gejala dan nilai bayes. 


\begin{tabular}{|c|c|c|c|c|}
\hline $\begin{array}{c}\text { Kode } \\
\text { Penyakit }\end{array}$ & Gejala & $\begin{array}{l}\text { Kode } \\
\text { Gejala }\end{array}$ & $\begin{array}{c}\text { Nilai } \\
\text { Gejala }\end{array}$ & $\begin{array}{l}\text { Nilai } \\
\text { Bayes }\end{array}$ \\
\hline \multirow{4}{*}{ P001 } & Pembusukan pada bagian pucuk tanaman & G1 & 0,5 & \multirow{4}{*}{1,5} \\
\hline & Tulang daun berubah warna kekuningan & $\mathrm{G} 2$ & 0,3 & \\
\hline & Terdapat pucuk tanaman mengecil & G3 & 0,5 & \\
\hline & Adanya pembusukan didaun & G4 & 0,2 & \\
\hline \multirow{4}{*}{ P002 } & Daun membusuk diujung & G5 & 0,5 & \multirow{4}{*}{1,3} \\
\hline & Terdapat bercak kuning didaun & G6 & 0,2 & \\
\hline & Terdapat lubang didaun & G7 & 0,3 & \\
\hline & Daun menggulung dan keriting & G8 & 0,3 & \\
\hline \multirow{3}{*}{ P003 } & Terdapat bintik putih dibelakang daun & G9 & 0,5 & \multirow{3}{*}{1,5} \\
\hline & Terdapat bintik putih dibatang & G10 & 0,5 & \\
\hline & Terdapat bintik putih diakar tanaman & G11 & 0,5 & \\
\hline \multirow{3}{*}{ P004 } & Tulang daun berubah warna kecoklatan & G12 & 0,5 & \multirow{3}{*}{1,3} \\
\hline & Batang dan akar tanaman mengecil & G13 & 0,4 & \\
\hline & Adanya pembusukan ditangkai daun & G14 & 0,4 & \\
\hline
\end{tabular}

Sumber : Upt Pengembangan Bibit Hortikultura Dan Peternakan Kota Medan

Tabel 3.4 Nilai Kepastian

\begin{tabular}{|c|c|c|}
\hline Range Bobot & Bilangan & Nilai \\
\hline $0 \mathrm{~s} / \mathrm{d} 0,3$ & Tidak Pasti & $0 \mathrm{~s} / \mathrm{d} 0,25$ \\
\hline $0,3 \mathrm{~s} / \mathrm{d} 0,5$ & Kurang Pasti & $0,25 \mathrm{~s} / \mathrm{d} 0,50$ \\
\hline $0,5 \mathrm{~s} / \mathrm{d} 0,6$ & Pasti & $0,50 \mathrm{~s} / \mathrm{d} 0,75$ \\
\hline 0,6 & Sangat Pasti & 1 \\
\hline
\end{tabular}

\subsubsection{Menghitung Dengan Metode Teorema Bayes}

Misalkan gejala yang tampak pada tanaman Bougenville ada 3 gejala yaitu Pembusukan Pada Pucuk Tanaman (G1), Terdapat Pucuk Tanaman Mengecil(G3), dan Terdapat bintik putih dibelakang daun (G9). Berdasarkan gejala tersebut maka dapat dihitung :

$P(H \mid E)=\frac{P(E \mid H) \cdot P(H)}{P(E)}$

1. Layu Bakteri (P001)

Jika probabilitas penyakit layu bakteri (P001) adalah : 1,5

Jika probabilitas gejala memandang penyakit adlah :

a. Pembusukan Pada Pucuk Tanaman (G1) : 0,5

b. Terdapat pucuk tanaman mengecil (G3) :0,5 
c. Terdapat bintik putih dibelakang daun $(\mathrm{G} 9)$ : 0

Perhitungan nilai Bayes :

1. $\mathrm{P}(\mathrm{P} 001) \mid \mathrm{G} 1)=\frac{P(G 1 \mid P 001) * P(P 001)}{P(G 1 \mid P 001) * P(P 001)+P(G 1 \mid P 02) * P(P 002)+C}$

$$
\begin{aligned}
& \frac{+(G 1 \mid P 001) * P(P 001)+P(G 1 \mid P 002) * P(P 002)+P(G 1 \mid P 003) * P(P 003)}{+P(G 1 \mid P 004) * P(P 004)} \\
& =\frac{0,5 * 1,5}{(0,5 * 1,5)+(0 * 1,3)+(0 * 1,5)+(0 * 1,3)} \\
& =\frac{0,75}{0,75} \\
& =1
\end{aligned}
$$

2. $\mathrm{P}(\mathrm{P} 001 \mid \mathrm{G} 3)=\frac{P(G 3 \mid P 001) * P(P 001)}{P(G 3 \mid P 001) * P(P 001)+P(G 3 \mid P 002) * P(P 002)+P(}$

$P(G 3 \mid P 001) * P(P 001)$

$$
\begin{aligned}
& +P(G 3 \mid P 002) * P(P 002)+P(G 3 \mid P 003) * P(P 003) \\
& =\frac{0,5 * 1,5}{(0,5 * 1,5)+(0 * 1,3)+(0 * 1,5)+(0 * 1,3)} \\
& =\frac{0,75}{0,75} \\
& =1
\end{aligned}
$$

3. $\mathrm{P}(\mathrm{P} 001 \mid \mathrm{G} 9) \quad P(G 9 \mid P 001) * P(P 001)$

$+P(G 9 \mid P 002) * P(P 002)+P(G 9 \mid P 003) * P(P 003)$ $+P(G 9 \mid P 009) * P(P 004)$

$$
\begin{aligned}
& =\frac{0 * 1,5}{(0 * 1,5)+(0 * 1,3)+(0,5 * 1,5)+(0 * 1,3)} \\
& =\frac{0}{0,75} \\
& =0
\end{aligned}
$$

Total Bayes $1=1+1+0=2$

2. Kutu Putih (P003)

Jika probabilitas Hama Mealybug (P003) adalah : 1,5

Jika probabilitas gejala memandang penyakit adalah :

a. Pembusukan pada bagian pucuk tanaman (G1): 0

b. Terdapat pucuk tanaman mengecil (G3) : 0

c. Terdapat bintik putih dibelakang daun (G9) : 0,5

Perhitungan nilai Bayes :

1. $\mathrm{P}(\mathrm{P} 003 \mid \mathrm{G} 1)=\frac{P(G 1 \mid P 003) * P(P 003)}{P(G 1 \mid P 001) * P(P 001)+P(G 1 \mid P 002) * P(P 02)+P(C}$ P(G1|P002)*P(P002)+P(G1|P003)*P(P003) $+P(G 1 \mid P 004) * P(P 004)$

$$
\begin{aligned}
& =\frac{0}{(0,5 * 1,5)+(0 * 1,3)+(0 * 1,5)+(0 * 1,3)} \\
& =\frac{0}{0,75} \\
& =0
\end{aligned}
$$

$P(G 2 \mid P 003) * P(P 003)$

$$
\begin{aligned}
& =\frac{0 * 1,5}{(0,5 * 1,5)+(0 * 1,3)+(0 * 1,5)+(0 * 1,3)} \\
& =\frac{0}{0,75} \\
& =0
\end{aligned}
$$

3. $\mathrm{P}(\mathrm{P} 003 \mid \mathrm{G} 9)=\frac{P(G 9 \mid P 003) * P(P 003)}{P(G 9 \mid P 001) * P(P 001)+P(G 9 \mid P 002) * P(P 002)+P(G 9 \mid P 003) * P(P 003)}$ $+P(G 9 \mid P 009) * P(P 004)$

$$
\begin{aligned}
& =\frac{0,5 * 1,5}{(0,5 * 1,5)+(0 * 1,3)+(0,5 * 1,5)+(0 * 1,3)} \\
& =\frac{0,75}{0,75}
\end{aligned}
$$




$$
=1
$$

Total Bayes $2=0+0+1=1$

Hasil $=$ Total Bayes $1+$ Total Bayes 2

$$
=2+1
$$

$=3$

Maka perhitungan probabilitas penyakitnya adalah :

1. Penyakit Layu Bakteri (P001)

$$
=2 / 3 * 100 \%=66,66 \%
$$

2. Kutu Putih (P003)

$=1 / 3 * 100 \%=33,33 \%$

Dari perhitungan menggunakan metode Teorema Bayes diatas, maka dapat diketahui bahwa diagnosa penyakit adalah Penyakit Layu Bakteri (P001) dengan nilai keyakinan 66,66\%.

\section{Implementasi Pengujian}

Implementasi merupakan langkah yang digunakan untuk mengoprasikan sistem yang dibangun. Berikut hasil implementasi sistem pakar untuk mendiagnosa penyakit dan hama penyerang tanaman Bougenville dengan menggunakan metode Teorema Bayes berbasis web.

\subsubsection{Form Menu Utama User (Home)}

Menu home merupakan menu utama dari program ini yang didalamnya terdapat penjelasan tentang tanaman Bougenville beserta manfaatnya.

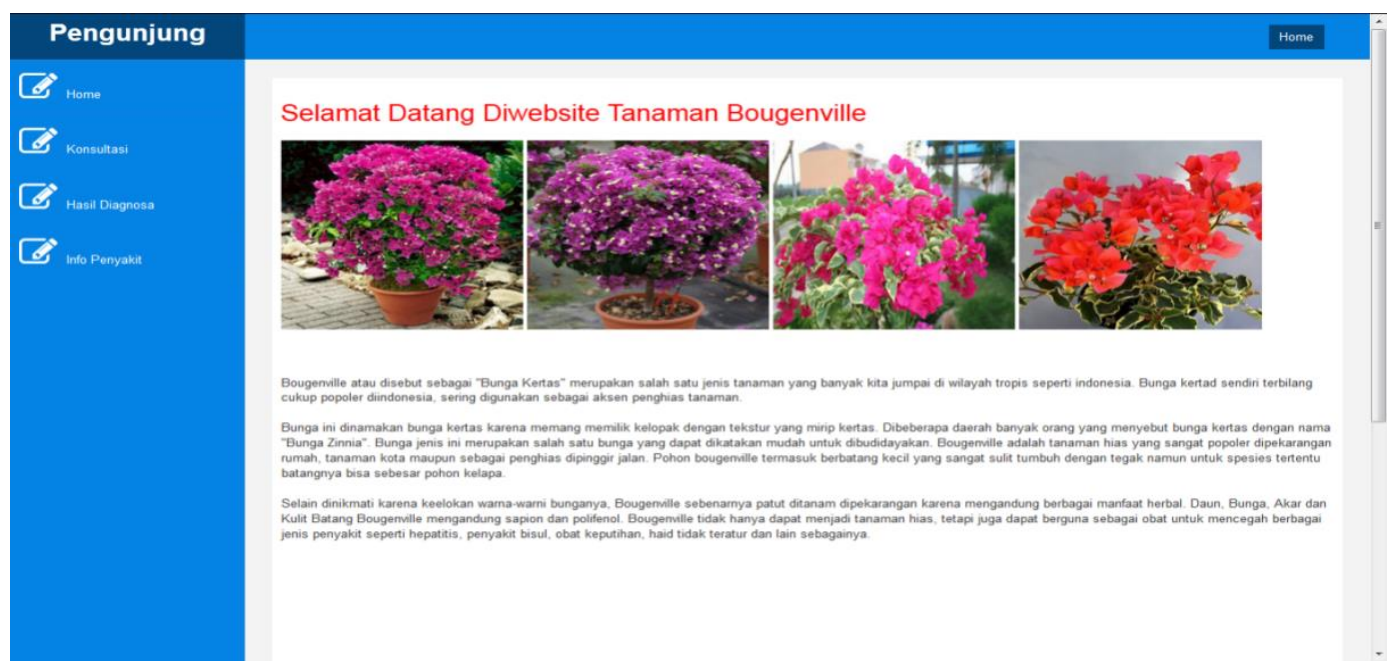

Gambar 4.1 Tampilan Form Menu Home

\subsubsection{Form Menu Konsultasi}

Form menu konsultasi berisikan form daftar. Dimana User diharuskan mendaftar terlebih dahulu untuk selanjutnya melakukan konsultasi. 


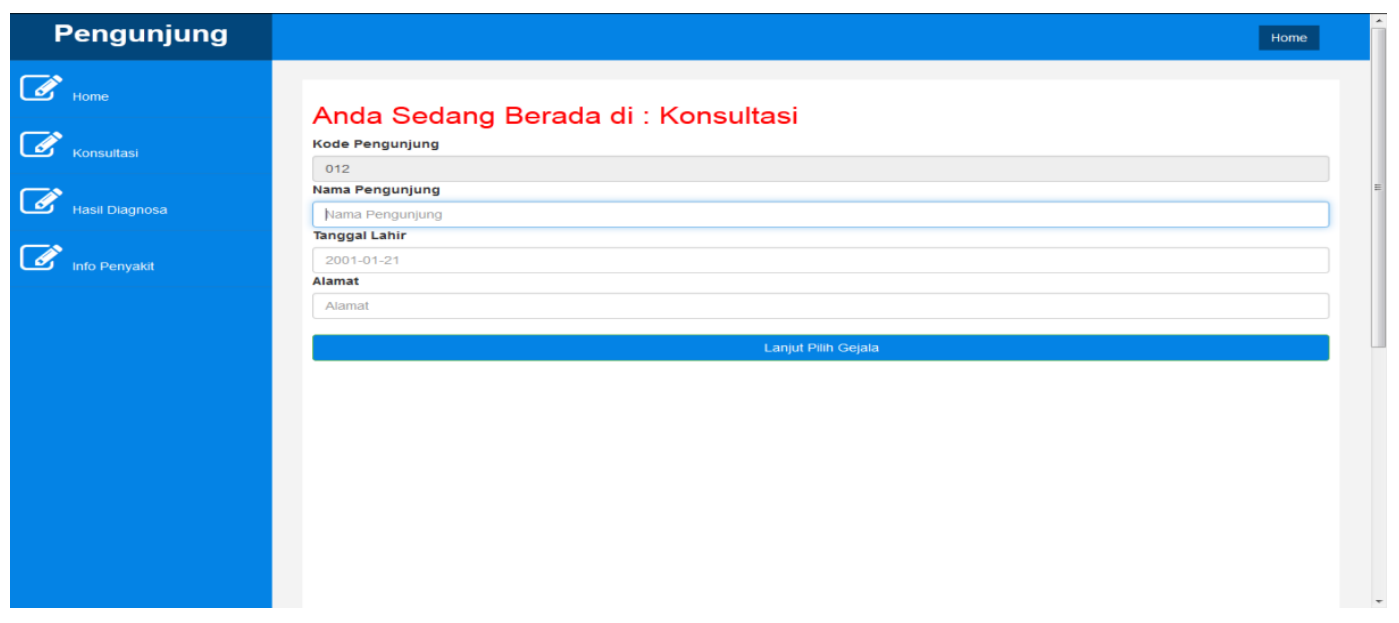

Gambar 4.2 Tampilan Form Menu Konsultasi

\subsubsection{Form Menu Hasil Diagnosa}

Form menu hasil diagnosa adalah form yang berisikan hasil penginputan identitas pengunjung beserta gejala yang telah dipilih

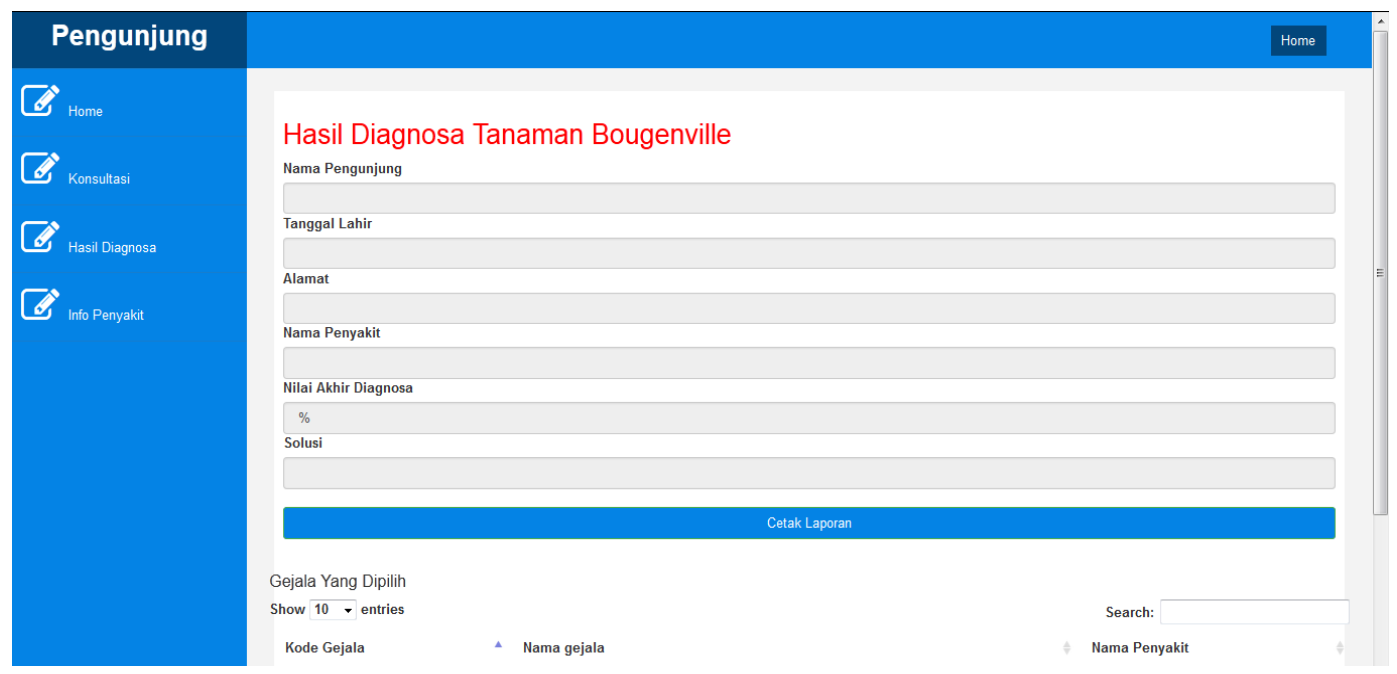

Gambar 4.3 Tampilan Form Hasil Diagnosa

\subsubsection{Form Menu Info Penyakit}

Form menu info penyakit adalah menu yang berisikan tentang informasi penyakit tanaman Bougenville 


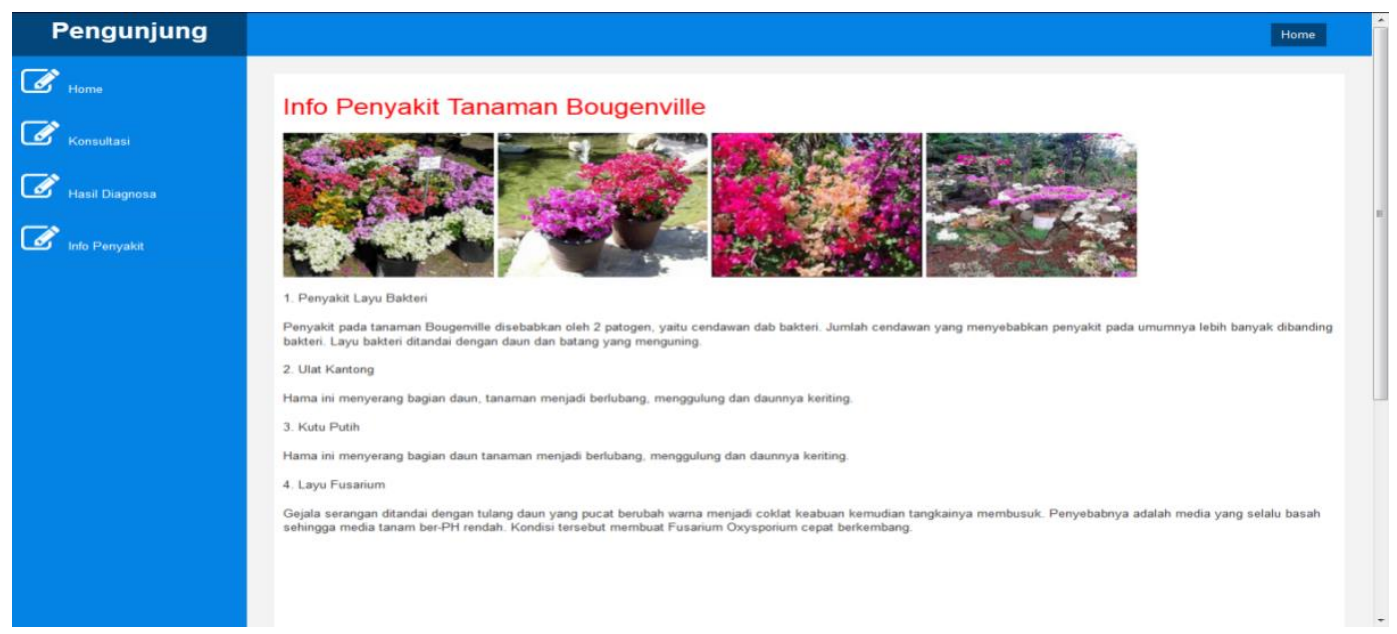

Gambar 4.4 Tampilan Form Menu Info Penyakit

\subsubsection{Form Login Admin}

Pada login admin, admin diharuskan untuk mengisi username dan password dengan benar agar dapat menggunakan menu yang terdapat pada login sebagai admin

\section{Login Sistem}

Admin
Username :
Your Username
Password :
Your password

\subsubsection{Menu Pengunjung Pada Halaman Admin}

Menu pengunjung pada halaman admin adalah menu yang dirancang untuk menyimpan data pengunjung. Tampilan menu pengunjung pada halaman admin dapat dilihat pada gambar dibawah ini :

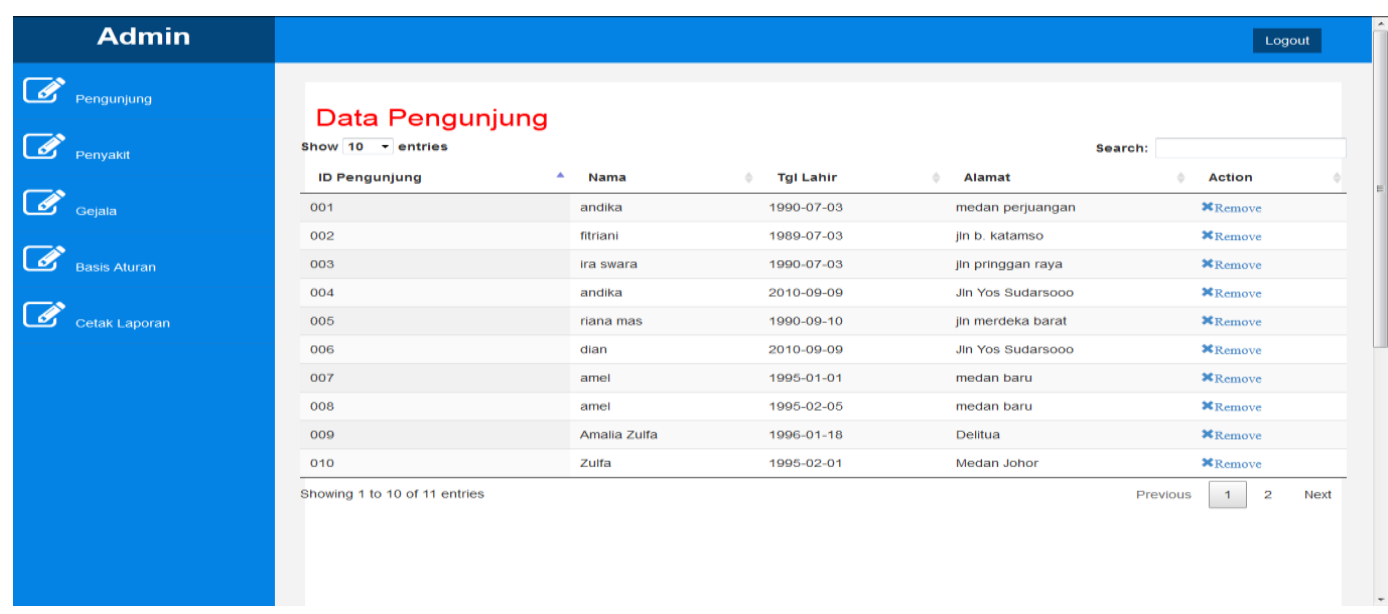

Jurnal SAINTIKOM Vol. 19, No. 1, Februari 2020:82-87 
Gambar 4.6 Tampilan Menu pengunjung pada halaman admin

\subsubsection{Menu Penyakit Pada Halaman Admin}

Menu penyakit pada halaman admin adalah menu yang dirancang untuk menyimpan data penyakit. Tampilan penyakit pada halaman admin dapat dilihat pada gambar dibawah ini :

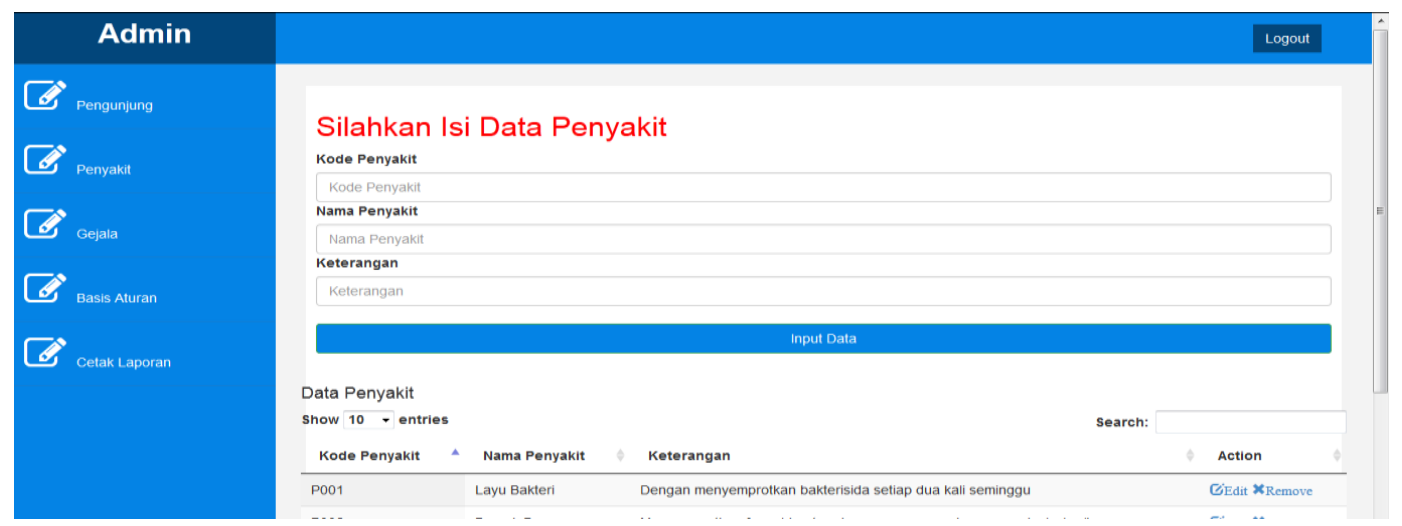

Gambar 4.7 Tampilan Menu penyakit pada halaman admin

Adapun fungsi dari tombol-tombol yang terdapat pada form menu penyakit yaitu :

1. Input Penyakit : Untuk menginput data penyakit

2. Edit

: Untuk melakukan perubahan dari data penyakit

3. Remove

: Untuk menghapus data penyakit dari database

\subsubsection{Menu Gejala Pada Menu Admin}

Menu gejala pada halaman admin adalah menu yang dirancang untuk menyimpan, merubah, dan menghapus data gejala. Tampilan menu gejala pada halaman admin dapat dilihat pada gambar dibawah ini :

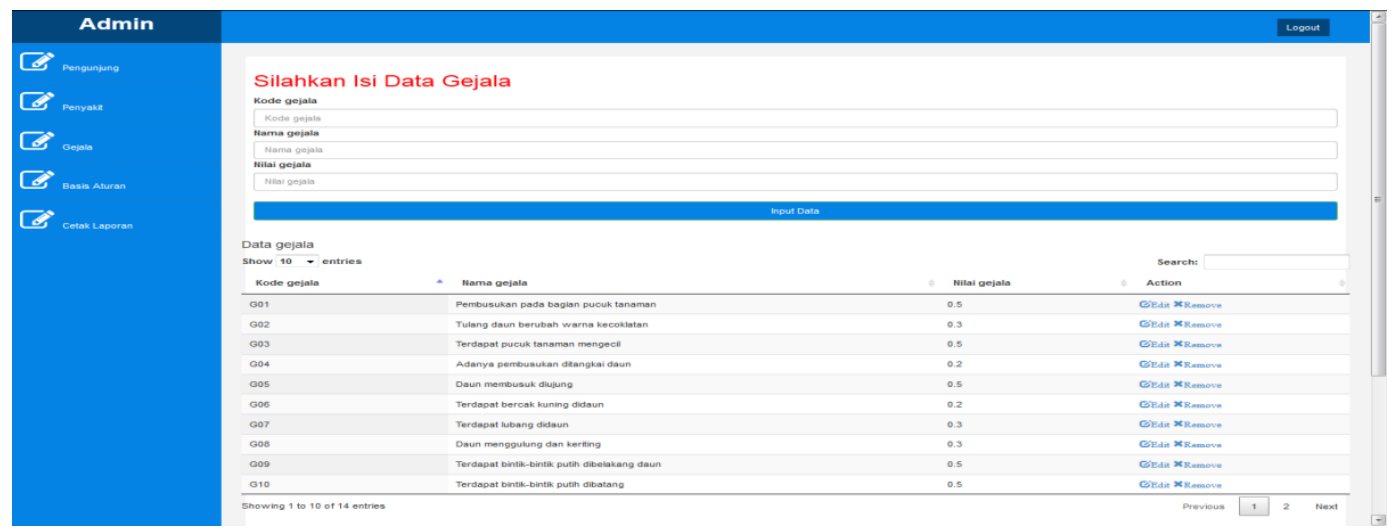

Gambar 4.8 Tampilan Menu gejala pada halaman admin

Adapun fungsi dari tombol-tombol yang terdapat pada form menu gejala yaitu :

1. Input Penyakit

: Untuk menginput data gejala

2. Edit

: Untuk melakukan perubahan dari data gejala

3. Remove

: Untuk menghapus data gejala dari database

\subsubsection{Menu Basis Aturan Pada Halaman Admin}

Menu basis aturan pada halaman admin adalah menu yang dirancang untuk menyimpan, merubah, dan menghapus data basis aturan. Tampilan menu basis aturan pada halaman admin dapat dilihat pada gambar dibawah ini : 


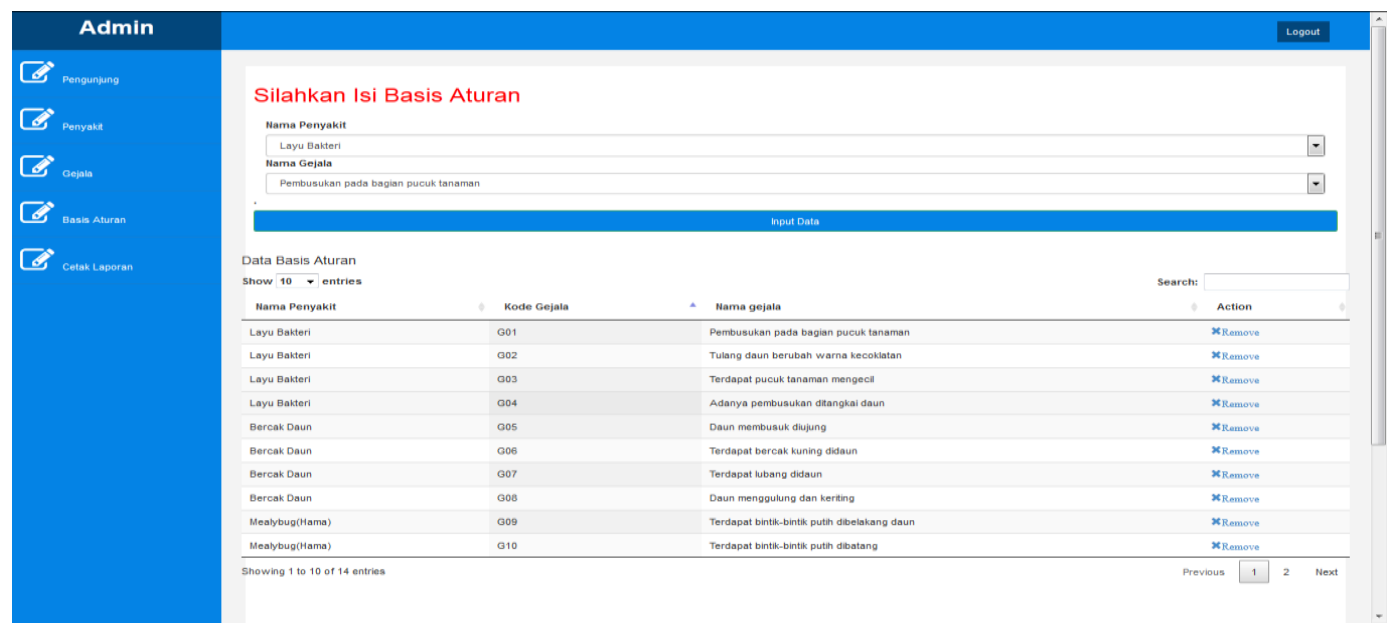

Gambar 4.9 Tampilan Menu basis aturan pada halaman admin

Adapun fungsi dari tombol-tombol yang terdapat pada form menu basis aturan yaitu :

1. Input Penyakit

2. Edit

3. Remove

: Untuk menginput data basis aturan

: Untuk melakukan perubahan dari data basis aturan

: Untuk menghapus data basis aturan dari database

\subsection{Pengujian Sistem}

Pengujian sistem terhadap sistem pakar untuk mendiagnosa penyakit dan hama penyerang tanaman Bougenville dilakukan dengan cara mengidentifikasi gejala yang ditemukan pada tanaman Bougenville kemudian melakukan perhitungan kepakaran menggunakan metode Teorema Bayes, berikut ini merupakan pengujian terhadap sistem pakar untuk mendiagnosa penyakit dan hama penyerang tanaman Bougenville

Misalkan ada seorang user ingin mengetahui penyakit ataupun hama yang menyerang tanaman Bougenville, dia diberi beberapa pilihan gejala kemudian memilih indikator gejala yang ditemukan pada tanaman Bougenville.

Form hasil pengujian Menu Diagnosa adalah sebagai berikut :

\subsubsection{Form Hasil Pengujian Menu Diagnosa}




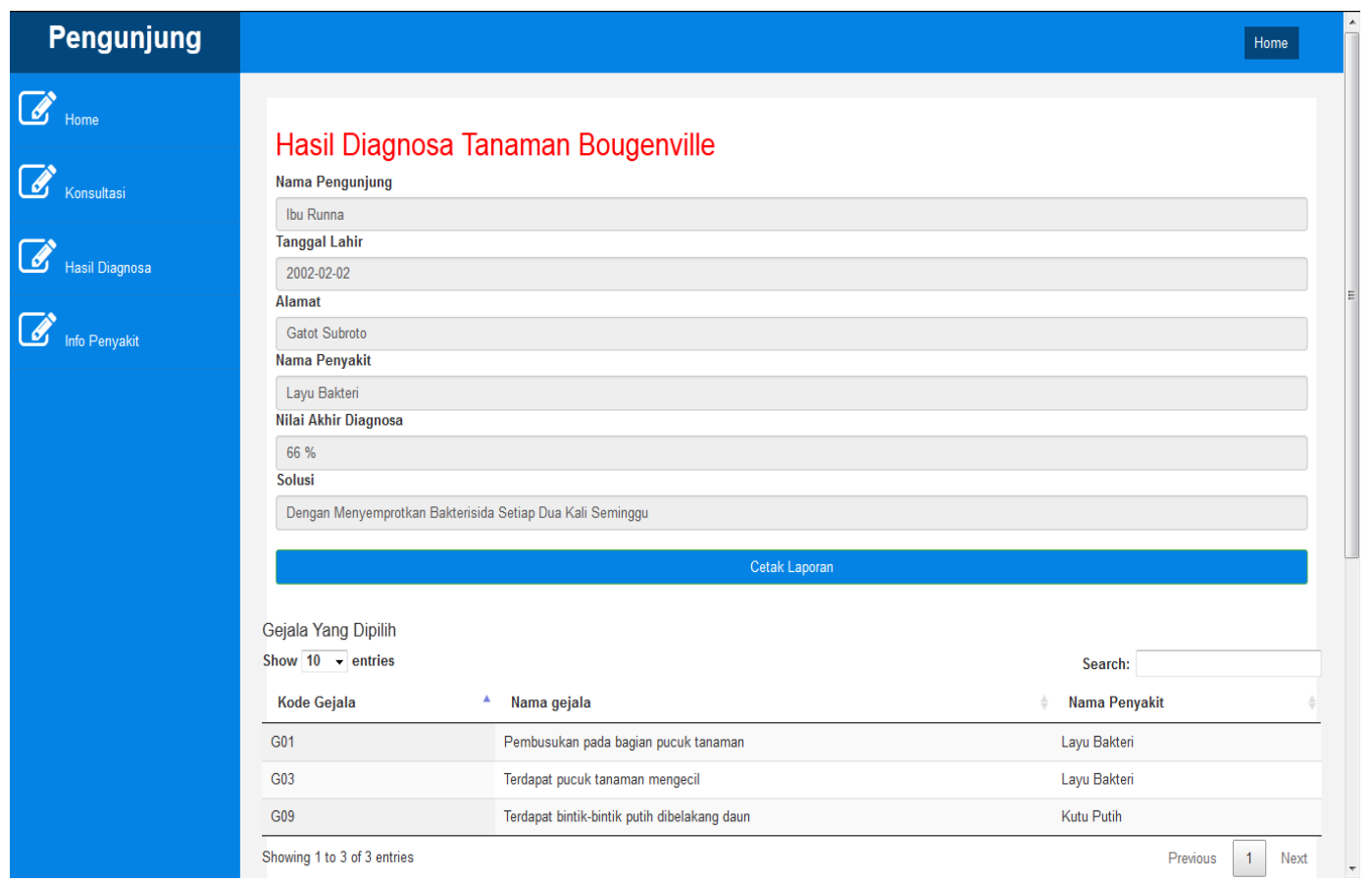

Gambar 4.10 Tampilan Form Hasil Pengujian Menu Diagnosa

\section{KESIMPULAN DAN SARAN}

\subsection{Kesimpulan}

Setelah penelitain selesai dilakukan, maka dapt ditarik beberapa kesimpulan sebagai penutup dari penelitian ini, Adapun beberapa kesimpulan yang diperoleh dari penelitian ini adalah sebagai berikut:

1. Sistem ini dapat menganalisa jenis penyakit dan hama penyerang tanaman Bougenville berdasarkan gejala yang dimasukkan oleh user atau pengguna

2. Metode Teorema Bayes dapat melakukan perhitungan yang cukup akurat dalam mendiagnosa penyakit dan hama tanaman Bougenville

3. Aplikasi sistem pakar untuk mendiagnosa penyakit dan hama penyerang tanaman Bougenvill ini dapat melakukan diagnosa awal terhadap suatu penyakit dan hama dan dapat dijadikan solusi alternative bagi masyarakat sebelum melakukan konsultasi langsung kepada pakar tersebut.

4. Dengan menggunakan aplikasi ini dapat mempermudah dalam mendiagnosa penyakit dan hama tanaman Bougenville, sehingga penanganannya dapat dilakukan dengan cepat

\subsection{Saran}

Untuk pengembangan selanjutnya maka disarankan beberapa hal sebagai berikut :

1. Diharapkan untuk pengembangan selanjutnya, sistem ini dapat mendiagnosa penyakit tanaman Bougenville dengan tingkat akurasi $100 \%$ bernilai benar.

2. Dalam memelihara keakuratan data pada aplikasi ini maka perlu dilakukan proses basis pengetahuan secara berkala

3. Sistem ini masih banyak kekurangan, oleh karena itu sangat dibutuhkan sebagai pengembangan lebih lanjut agar dapat memberikan lebih banyak lagi manfaat untuk para pencinta tanaman Bougenville

\section{UCAPAN TERIMA KASIH}

Terima kasih kepada dosen pembimbing Bapak Beni Andika,ST.,M.Kom, Bapak Suardi Yakub SE.,MM dan pihak - pihak lainnya yang mendukung penyelesaian jurnal skripsi ini.

\section{REFERENSI}

[1] T.Sutojo, Mulyanto, \& Suhartono, V., 2017, Kecerdasan Buatan, Yogyakarta, Andi Offiset

[2] Teguh El Real.Tanaman Hias Bunga, Daun \& Bonsai.2016:38 
[3] Zulfian Azmi, dkk 2018. Implementasi Teorema Bayes Untuk Mendiagnosa Tingkat Stres. Jurnal JISIKOM Vol.2 No.1

[4] Sulindawati dan Muhammad Fathoni. 2010. Pengantar Analisa Perancangan Sistem Jurnal Saintikom, Vol.9 No 2

[5] Rosa,A.S., \& Shalahuddin,M., 2015, Rekayasa Perangkat Lunak, Bandung, Informatika 